\title{
Circulating cancer stem cells: an interesting niche to explore
}

\author{
Federica Papaccio* (1) \\ Department of Medicine, Surgery and Dentistry "Scuola Medica Salernitana", University of Salerno, Via S. Allende, 84081 \\ Baronissi (SA), Italy
}

*Correspondence: Federica Papaccio, Department of Medicine, Surgery and Dentistry "Scuola Medica Salernitana", University of Salerno, Via S. Allende, 84081 Baronissi (SA), Italy. fede.papaccio@yahoo.it; fpapaccio@unisa.it

Academic Editor: Floriana Morgillo, Università degli studi della Campania, Italy

Received: May 14, 2020 Accepted: July 21, 2020 Published: August 31, 2020

Cite this article: Papaccio F. Circulating cancer stem cells: an interesting niche to explore. Explor Target Antitumor Ther. 2020;1:253-8. https://doi.org/10.37349/etat.2020.00016

Cancer stem cells (CSCs) constitute a relevant subpopulation of cells within the tumor from the beginning of its development. They are the tumor initiating cells, capable of self-renewal and multiple differentiating potential [1-3]; these particular cells are responsible for resistance to radiotherapy and chemotherapy, and ultimately disease recurrence and progression in cancer patients [4]. As a consequence, eradicating this subpopulation would be critical in order to achieve patient's cure $[5,6]$.

Circulating tumor cells (CTCs) are cancer cells that are shed into the blood system even at very early stage of cancer development [7], being a promising tool for detection of minimal residual disease and progression [8-10]. Their concentration correlates with high tumor burden, offering a prognostic tool [11]. Nevertheless, CTCs detection and isolation still remains challenging from a technical point of view, particularly when searching for a standardized reproducible method, which is critical when looking for a clinical application [12-14]. Indeed, despite all the efforts, CTCs exploration has not been widely diffused. The only FDA approved technology for CTCs detection is CellSearch, since 1999 [15]. This is an immune-affinity enrichment method, based on the detection of the epithelial cell adhesion membrane (EpCAM) protein.

Some experiences are published about the detection of CTCs in lung cancer patients as a diagnostic and prognostic tool [16-19]. Actually, liquid biopsy is an interesting field of investigation in lung cancer for several important reasons. Lung cancer is the leading cause of cancer related deaths worldwide, it is often diagnosed in advanced stage; moreover, despite the importance of molecular profiling of these tumors in order to offer a personalized treatment, often tissue biopsies are technically difficult. Indeed, CTCs isolation and characterization for driver mutations is feasible and could offer a clear advantage over classical tissue biopsies [20], increasing the number of patients who can access to molecularly-guided therapy.

Interestingly, some experimental findings have highlighted that a small proportion of CTCs displays CSCs features (tumor initiating capability, in particular), so that they can be considered as circulating tumor stem cells (CTSCs) [21-23]. For this reason, the investigation towards the identification of CTCs and their potential role in metastasis has increased over the last years [24-26]. This finding holds important implications as stem population is highly tumorigenic and so targeting it could be crucial towards the prevention of disease progression [27]. Indeed, to improve CTSCs isolation is of outmost importance.

CTSCs have been identified in several solid tumors, such as colorectal cancer [28] and breast cancer [19].

\footnotetext{
(C) The Author(s) 2020. This is an Open Access article licensed under a Creative Commons Attribution 4.0 International License (https://creativecommons.org/licenses/by/4.0/), which permits unrestricted use, sharing, adaptation, distribution and reproduction in any medium or format, for any purpose, even commercially, as long as you give appropriate credit to the original author(s) and the source, provide a link to the Creative Commons license, and indicate if changes were made.
} 
A preliminary study combined different surface markers including epithelial (cytokeratin and EpCAM) and CSC markers [CD44, Aldehyde dehydrogenase (ALDH), and CD24] aiming at increase the sensitivity of the assay over a one marker approach [29]. This study has been conducted on CTCs isolated from peripheral blood of non-small cell lung cancer (NSCLC) patients and has been functionally validated: the CTSCs were able to form pleurospheres in vitro, which is among the definition criteria of CSCs [30].

The potential prognostic value was already highlighted in a 2011 paper where CTSCs predicted recurrence in hepatocellular carcinoma patients after surgical resection [31]. In a later paper, circulating CD44+ CSCs could predict risk of recurrence in gastric cancer patients [32].

Actually, CD44+ CTSCs have been identified in NSCLC patients. Their levels were inversely correlated with serum tumor necrosis factor-related apoptosis-inducing ligand (sTRAIL) levels, which have been associated with a tumor suppressive effect [33]. In another study, sTRAIL was negatively correlated with ALDH1+ cells, the latter being a different marker which can be used for NSCLC CTSCs characterization [34].

Another point to be considered is that within CTSCs there are distinct sub-populations, and that those expressing epithelial-mesenchymal transition (EMT) features could be an even more aggressive subtype [35]. The coexistence of CSC and EMT markers has been demonstrated on breast cancer CTCs [19, 36, 37]. Indeed, this complex phenotype prevails in more advanced and metastatic cases [37]. In addition, it was demonstrated that this subpopulation is more drug resistant than the other subtypes [38].

The heterogeneity of cell populations can be detected also among CTSCs that display mesenchymal or epithelial phenotypes: in a cohort of 43 NSCLC patients it was detected the presence of both epithelial and mesenchymal CTSCs subpopulations. Cells with mesenchymal features had a phenotype that correlated with stemness and with a more aggressive behavior, including a reduced progression free survival [39]. On the other hand, the phenotypic heterogeneity of CTSCs could encourage the use of multiple markers in order to allow a better caption of all the stem population [40].

New insights on CSTCs will surely come from single-cell technology studies. A recently published study employed a multigene nanoplatform to evaluate gene expression on hundreds of single CTCs from lung cancer patients [41].

CTCs from lung cancer patients bear an incredible potential, from gene mutation to gene expression, and could help to capture cancer heterogeneity and evolution when analyzed as single cell. Thus, they could be of potential relevance for progression monitoring and molecularly guided treatment decision, improving precision medicine. Tremendous applications are represented by the possibility to isolate CTCs for cell culture, which allowed to create CTC-derived xenografts [42] in animal models and more recently organoids culture [43], for drug screening as an example. Clearly, this constitutes an added value compared with other liquid biopsy techniques, relying for example on circulating DNA isolation. Nevertheless, there are several issues to consider: first of all, the fact that CTCs and even more CSTCs are difficult and rare to detect [44]. The majority of enrichment methods are based on the epithelial marker EpCAM, which is often not expressed in the stem/EMT compartment. Furthermore, for cell culture it is needed a system capable of ensuring a high viability of cells after sorting [45]. Emerging enrichment technologies are employing electrochemical methods, thus avoiding the selection of surface markers [46, 47].

Certainly, more attention should be focused on the possibility to isolate the stem/EMT population directly from the patient, as it has been showed in a significant breast cancer patients' cohort [48] and possibly in the future to perform functional studies on this specific cells. This approach could allow for instance to screen drugs on putative stem-related oncogenic vulnerabilities $[49,50]$.

\section{Abbreviations}

ALDH: Aldehyde dehydrogenase

CSCs: cancer stem cells

CTCs: circulating tumor cells

CTSCs: circulating tumor stem cells 
EMT: epithelial-mesenchymal transition

EpCAM: epithelial cell adhesion membrane

NSCLC: non-small cell lung cancer

STRAIL: serum tumor necrosis factor-related apoptosis-inducing ligand

\section{Declarations}

\section{Author contributions}

The author contributed solely to the work.

\section{Conflicts of interest}

The author declares that he has no conflicts of interest.

\section{Ethical approval}

Not applicable.

\section{Consent to participate}

Not applicable.

\section{Consent to publication}

Not applicable.

\section{Availability of data and materials}

Not applicable.

\section{Funding}

Not applicable.

\section{Copyright}

(c) The Author(s) 2020.

\section{References}

1. Reya T, Morrison SJ, Clarke MF, Weissman IL. Stem cells, cancer, and cancer stem cells. Nature. 2001;414:105-11.

2. Tirino V, Desiderio V, Paino F, De Rosa A, Papaccio F, La Noce M, et al. Cancer stem cells in solid tumors: an overview and new approaches for their isolation and characterization. FASEB J. 2013;27:13-24.

3. Papaccio F, Paino F, Regad T, Papaccio G, Desiderio V, Tirino V. Concise Review: Cancer cells, cancer stem cells, and mesenchymal stem cells: influence in cancer development. Stem Cells Transl Med. 2017;6:2115-25.

4. Vinogradova TV, Chernov IP, Monastyrskaya GS, Kondratyeva LG, Sverdlov ED. Cancer stem cells: plasticity works against therapy. Acta Naturae. 2015;7:46-55.

5. Dingli D, Michor F. Successful therapy must eradicate cancer stem cells. Stem Cells. 2006;24:2603-10.

6. Klonisch T, Wiechec E, Hombach-Klonisch S, Ande SR, Wesselborg S, Schulze-Osthoff K et al. Cancer stem cell markers in common cancers - therapeutic implications. Trends Mol Med. 2008;14:450-60.

7. Hanssen A, Loges S, Pantel K, Wikman H. Detection of circulating tumor cells in non-small cell lung cancer. Front Oncol. 2015;5:207.

8. Lianidou ES, Markou A, Strati A. The role of CTCs as tumor biomarkers. Adv Exp Med Biol. 2015;867:341-67. 
9. van de Stolpe A, Pantel K, Sleijfer S, Terstappen LW, den Toonder JM. Circulating tumor cell isolation and diagnostics: toward routine clinical use. Cancer Res. 2011;71:5955-60.

10. van de Stolpe A, den Toonder JM. Circulating tumor cells: what is in it for the patient? A vision towards the future. Cancers (Basel). 2014;6:1195-207.

11. Krebs MG, Metcalf RL, Carter L, Brady G, Blackhall FH, Dive C. Molecular analysis of circulating tumour cells-biology and biomarkers. Nat Rev Clin Oncol. 2014;11:129-44.

12. Harouaka R, Kang Z, Zheng SY, Cao L. Circulating tumor cells: advances in isolation and analysis, and challenges for clinical applications. Pharmacol Ther. 2014;141:209-21.

13. Tognela A, Spring KJ, Becker T, Caixeiro NJ, Bray VJ, Yip PY, et al. Predictive and prognostic value of circulating tumor cell detection in lung cancer: a clinician's perspective. Crit Rev Oncol Hematol. 2015;93:90-102.

14. Coumans FA, Ligthart ST, Uhr JW, Terstappen LW. Challenges in the enumeration and phenotyping of CTC. Clin Cancer Res. 2012;18:5711-8.

15. Tibbe AG, de Grooth BG, Greve J, Liberti PA, Dolan GJ, Terstappen LW. Optical tracking and detection of immunomagnetically selected and aligned cells. Nat Biotechnol. 1999;17:1210-3.

16. Yu N, Zhou J, Cui F, Tang X. Circulating tumor cells in lung cancer: detection methods and clinical applications. Lung. 2015;193:157-71.

17. Hou JM, Krebs M, Ward T, Sloane R, Priest L, Hughes A, et al. Circulating tumor cells as a window on metastasis biology in lung cancer. Am J Pathol. 2011;178:989-96.

18. Gauler TC, Theegarten D, Parr A, Schuhr I, Schmid KW, Eberhardt W, et al. Decrease of circulating tumor cells associates with response to platinum-based chemotherapy in patients with non-small cell lung cancer, but not with small cell lung cancer. J Thorac Oncol. 2011;6:S1114.

19. Krebs MG, Sloane R, PriestL, Lancashire L, Hou JM, Greystoke A, etal. Evaluation and prognostic significance of circulating tumor cells in patients with non-small-cell lung cancer. J Clin Oncol. 2011;29:1556-63.

20. Maheswaran S, Sequist LV, Nagrath S, Ulkus L, Brannigan B, Collura CV, et al. Detection of mutations in EGFR in circulating lung-cancer cells. N Engl J Med. 2008;359:366-77.

21. Theodoropoulos PA, Polioudaki H, Agelaki S, Kallergi G, Saridaki Z, Mavroudis D, et al. Circulating tumor cells with a putative stem cell phenotype in peripheral blood of patients with breast cancer. Cancer Lett. 2010;288:99-106.

22. Krawczyk N, Meier-Stiegen F, Banys M, Neubauer H, Ruckhaeberle E, Fehm T. Expression of stem cell and epithelial-mesenchymal transition markers in circulating tumor cells of breast cancer patients. Biomed Res Int. 2014;2014:415721.

23. Scatena R, Bottoni P, Giardina B. Circulating tumour cells and cancer stem cells: a role for proteomics in defining the interrelationships between function, phenotype and differentiation with potential clinical applications. Biochim Biophys Acta. 2013;1835:129-43.

24. Dittmar T, Heyder C, Gloria-Maercker E, Hatzmann W, Zanker KS. Adhesion molecules and chemokines: the navigation system for circulating tumor (stem) cells to metastasize in an organ-specific manner. Clin Exp Metastasis. 2008;25:11-32.

25. Lambert AW, Pattabiraman DR, Weinberg RA. Emerging biological principles of metastasis. Cell. 2017;168:670-91.

26. Luo YT, Cheng J, Feng X, He SJ, Wang YW, Huang Q. The viable circulating tumor cells with cancer stem cells feature, where is the way out? J Exp Clin Cancer Res. 2018;37:38.

27. Barriere G, Fici P, Gallerani G, Fabbri F, Zoli W, Rigaud M. Circulating tumor cells and epithelial, mesenchymal and stemness markers: characterization of cell subpopulations. Ann Transl Med. 2014;2:109. 
28. Kantara C, O'Connell MR, Luthra G, Gajjar A, Sarkar S, Ullrich RL et al. Methods for detecting circulating cancer stem cells (CCSCs) as a novel approach for diagnosis of colon cancer relapse/metastasis. Lab Invest. 2015;95:100-12.

29. Mirza S, Jain N, Rawal R. Evidence for circulating cancer stem-like cells and epithelial-mesenchymal transition phenotype in the pleurospheres derived from lung adenocarcinoma using liquid biopsy. Tumour Biol. 2017;39:1010428317695915.

30. Tinhofer I, Saki M, Niehr F, Keilholz U, Budach V. Cancer stem cell characteristics of circulating tumor cells. Int J Radiat Biol. 2014;90:622-7.

31. Fan ST, Yang ZF, Ho DW, Ng MN, Yu WC, WongJ. Prediction of posthepatectomy recurrence of hepatocellular carcinoma by circulating cancer stem cells: a prospective study. Ann Surg. 2011;254:569-76.

32. Li M, Zhang B, Zhang Z, Liu X, Qi X, Zhao J, et al. Stem cell-like circulating tumor cells indicate poor prognosis in gastric cancer. Biomed Res Int. 2014;2014:981261.

33. Sun YB, Sun GH, Xu S, Xu JJ. Tumor-suppressive activity of sTRAIL on circulating CD44+ cells in patients with non-small cell lung cancer. Biol Chem. 2020;401:417-22.

34. Tian S, Xing YN, Xia P. The prognostic roles of circulating ALDH1+ tumor cell in the patients with nonsmall cell lung cancer. Biosci Rep. 2018;38:BSR20180914.

35. Alix-Panabières C, Mader S, Pantel K. Epithelial-mesenchymal plasticity in circulating tumor cells. J Mol Med (Berl). 2017;95:133-42.

36. Kallergi G, Papadaki MA, Politaki E, Mavroudis D, Georgoulias V, Agelaki S. Epithelial to mesenchymal transition markers expressed in circulating tumour cells of early and metastatic breast cancer patients. Breast Cancer Res. 2011;13:R59.

37. Papadaki MA, Kallergi G, Zafeiriou Z, Manouras L, Theodoropoulos PA, Mavroudis D, et al. Co-expression of putative stemness and epithelial-to-mesenchymal transition markers on single circulating tumour cells from patients with early and metastatic breast cancer. BMC Cancer. 2014;14:651.

38. Papadaki MA, Stoupis G, Theodoropoulos PA, Mavroudis D, Georgoulias V, Agelaki S. Circulating tumor cells with stemness and epithelial-to-mesenchymal transition features are chemoresistant and predictive of poor outcome in metastatic breast cancer. Mol Cancer Ther. 2019;18:437-47.

39. Nel I, Jehn U, Gauler T, Hoffmann AC. Individual profiling of circulating tumor cell composition in patients with non-small cell lung cancer receiving platinum based treatment. Transl Lung Cancer Res. 2014;3:100-6.

40. Savelieva OE, Tashireva LA, Kaigorodova EV, Buzenkova AV, Mukhamedzhanov RK, Grigoryeva ES, et al. Heterogeneity of stemlike circulating tumor cells in invasive breast cancer. Int J Mol Sci. 2020;21:2780.

41. Park S, Wongc DJ, Ooid CC, Kurtz DM, Vermesh O, Aalipoura A, et al. Molecular profiling of single circulating tumor cells from lung cancer patients. Proc Natl Acad Sci U S A. 2016;113:E8379-86.

42. Drapkin BJ, George J, Christensen CL, Mino-Kenudson M, Dries R, Sundaresan T, et al. Genomic and functional fidelity of small cell lung cancer patient-derived xenografts. Cancer Discov. 2018;8:600-15.

43. Stewart CA, Gay CM, Xi Y, Sivajothi S, Sivakamasundari V, Fujimoto J, et al. Single-cell analyses reveal increased intratumoral heterogeneity after the onset of therapy resistance in small-cell lung cancer. Nature Cancer. 2020;1:423-36.

44. Nagrath S, Sequist LV, Maheswaran S, Bell DW, Irimia D, Ulkus L, et al. Isolation of rare circulating tumour cells in cancer patients by microchip technology. Nature. 2007;450:1235-9.

45. Praharaj PP, Bhutia SK, Nagrath S, Bitting RL, Deep G. Circulating tumor cell-derived organoids: current challenges and promises in medical research and precision medicine. Biochim Biophys Acta Rev Cancer. 2018;1869:117-27.

46. Wang SS, Zhao XP, Liu FF, Younis MR, Xia XH, Wang C. Direct plasmon-enhanced electrochemistry for enabling ultrasensitive and label-free detection of circulating tumor cells in blood. Anal Chem. 2019;91:4413-20. 
47. Cao J, Zhao XP, Younis MR, Li ZQ, Xia XH, Wang C. Ultrasensitive capture, detection, and release of circulating tumor cells using a nanochannel-ion channel hybrid coupled with electrochemical detection technique. Anal Chem. 2017;89:10957-64.

48. Baccelli I, Schneeweiss A, RiethdorfS, Stenzinger A, Schillert A, Vogel V, et al. Identification of a population of blood circulating tumor cells from breast cancer patients that initiates metastasis in a xenograft assay. Nat Biotechnol. 2013;31:539-544.

49. Mendonça L, Trindade A, Carvalho C, Correia J, Badenes M, Gigante J, et al. Metastasis is impaired by endothelial-specific Dll4 loss-of-function through inhibition of epithelial-to-mesenchymal transition and reduction of cancer stem cells and circulating tumor cells. Clin Exp Metastasis. 2019;36:365-80.

50. La Noce M, Paino F, Mele L, Papaccio G, Regad T, Lombardi A, et al. HDAC2 depletion promotes osteosarcoma's stemness both in vitro and in vivo: a study on a putative new target for CSCs directed therapy. J Exp Clin Cancer Res. 2018;37:296. 